\title{
PENDIDIKAN AGAMA DAN KEKERASAN PADA ANAK (CHILD ABUSE) PERSPEKTIF PENDIDIKAN ISLAM
}

\author{
Muhamad Tisna Nugraha \\ Dosen Fakultas Tarbiyah dan Ilmu Keguruan IAIN Pontianak \\ Email: tisnanugraha2014@yahoo.com
}

\begin{abstract}
The case of violences in education is often seen in Indonesia. The education institution should appropriately be the place to create the real mankind. Furthermore, it also prepares the smart generation, emotionally and spiritually. Despite it is not always a core of student development. Moreover, the abuse acts always happening are the indicator that the education process is still far from bumanity values.

Education, furthermore, is not only the obligation of spiritual dedication, especially for Moslem man and woman, but also as a place that should produce the scholars. Besides, they are prepared for accomplishing the bumanity problems, for instance, poverty, idiocy, suppression, and terrorism. Therefore, education contributes to prevent and reduce conflict. Then, it is also designed specifically to counter violences. Overall, a concept of effective education of applying the study method absorbed by religious and cultural values.
\end{abstract}

Keywords: Religious, Education, Children, Abuse

\section{PENDAHULUAN}

Kekerasan dalam pendidikan bukanlah merupakan hal yang baru. Sebuah prakarsa yang mengedepankan pencapaian hasil maksimal melalui segala upaya atas nama kebenaran ilmu pengetahuan. Ini adalah suatu tujuan yang sangat mulia, tetapi disisi lain mengenyampingkan sisi kemanusian dan budaya ketimuran. Masih ingat dalam benak kita, peristiwa kekerasan di Institut Pemerintahan Dalam Negeri (IPDN) yang dilakukan senior tehadap junior di tahun 2003 yang menewasakan Wahyu Hidayat dan seorang praja lainnya yang bernama Cliff Muntu di tahun 2007.

Tidak hanya IPDN, di tahun 2014 kasus kekerasan juga ikut merengut nyawa Dimas Dikita Handoko salah seorang siswa di Sekolah Tinggi Ilmu Pelayaran (STIP). Disusul lagi dengan kasus seksual terhadap siswa Taman Kanak-Kanak di sekolah bertaraf internasional Jakarta International School (JIS) tahun 2014. Berbagai kasus-kasus tersebut semakin menambah panjang daftar jumlah korban yang yang berjatuhan dalam lembaga kependidikan, dan hal ini seakan mengindikasikan bahwa dunia pendidikan di tanah air telah menebar teror bagi anak didiknya sendiri.

Memang, situasi di Indonesia saat ini belum separah seperti yang dialami negara-negara yang sedang menghadapi konflik di Timur Tengah, diantaranya Palestina, Suriah, dan Irak. Anakanak di daerah tersebut seperti telah dilatih untuk mengenal senjata dan berhadapan dengan maut setiap harinya. Bahkan di wilayah tertentu pernah tercatat pada tahun 1991, pemberontakan Sierra Leone, Afrika telah memaksa anak-anak mereka menjadi tentara yang kejam terhadap warga sipil setelah terlebih dahulu mereka menyaksikan orangtuanya dibunuh. 
Persoalan ini kemudian semakin kompleks ketika kurikulum yang ada di sekolah telah ditemukan beberapa materi dalam buku pelajaran khususnya pada mata pelajaran agama yang menjurus pada aksi kekerasan. Kasus ini juga terjadi di beberapa wilayah di Indonesia, sehingga meresahkan para orangtua, masyarakat dan pemerhati masalah pendidikan, yang pada gilirannya di awal tahun 2015 Kementerian Pendidikan dan Kebudayaan (Kemendikbud) kemudian memutuskan untuk menarik buku Pendidikan Agama Islam yang mengajarkan kekerasan tersebut.

Kekerasan dalam ajaran agama bukanlah hal yang dibenarkan bahkan sangat dilarang dengan keras. Namun pada kenyataannya, anjuran-anjuran dalam materi agama jika dipahami setengah-setengah, justru mengarahkan seseorang pada kekerasan yang terselubung dibalik paradigma pendidikan. Sebagai contoh anjuran untuk mempersenjatai diri sebagaimana riwayat Umar bin Khatab dalam Yusuf Al-Qardhawi (2013: 986) sebagai berikut: Khalifah Umar bin Khatab ra, pernah menganjurkan "ajarkan kepada anak-anakmu berenang, memanah dan menunggang kuda".

Anjuran tersebut, seolah menjadi legitimasi bagi setiap orangtua untuk mengajarkan serta mempersenjatai anaknya. Anak seolah tidak hanya dituntut untuk dapat hidup dalam suasana yang keras, namun juga mampu menghadapi berbagai persoalan yang datang pada dirinya dengan tegas. Meskipun dalam konteks ini lebih kepada dunia pendidikan militer yang berbeda dengan pendidikan secara umum.

Tidak hanya dalam Islam, Yesus yang banyak mengajarkan cinta kasih serta suri tauladan yang baik bagi para pengikutnya juga pernah melakukan tindakan tegas untuk penyucian Bait Allah dengan cara menjungkirbalikan meja para penukar uang serta mengobrak-abrik perabotannya, sehingga koin-koin dan merpati di Bait Allah kemudian berhamburan. Hal ini sebagaimana dikemukakan Andar Ismail (2008: 48) bahwa Yohanes berkata: "ia membuat cambuk dari tali lalu mengusir mereka semua dari Bait Suci dengan semua kambing, domba dan lembu mereka; uang penukar-penukar dihamburkan-Nya. Selain itu, Yesus yang hendak meninggikan derajat sesorang terkadang juga memberikan ujian secara langsung kepada orang yang hendak ditinggikannyanya. Hal ini sebagaimana dikemukakan Nico Ter Linden (2008: 166) dalam rujukan Kitab Perjanjian Lama (Kejadian (32): 22-23), yang menyatakan bahwa: "Ishak yang memperanakkan Yakub, kemudian hari nama Yakub akan menjadi Israel karena keberaniannya yang gigih bergumul (bergulat) dengan Allah dan manusia.

Dari berbagai penjelasan di atas, maka tulisan ini dimaksudkan untuk mengkaji lebih lanjut praktik dalam pendidikan agama dengan berbagai kasus kekerasan yang terjadi pada anak (child abuse). Selain itu tulisan ini juga diharapkan dapat menjadi khazanah yang menambah wawasan berpikir serta meningkatkan perhatian pembaca terhadap permasalahan yang dihadapi oleh anak dan berupaya untuk mencari solusinya.

\section{PENDIDIKAN AGAMA DAN KEKERASAN}

Menurut Tim Pengembangan Ilmu Pendidikan (2009: xi), menyatakan bahwa: Pendidikan adalah usaha sadar dan sistematis yang dilakukan tidak hanya untuk memanusiakan manusia tetapi juga agar manusia menyadari posisinya sebagai khalifatullah fil ardi, yang pada gilirannya akan semakin meningkatkan dirinya untuk menjadi manusia yang bertaqwa, beriman, berilmu dan beramal saleh. 
Pendidikan yang berlaku di Indonesia saat ini dikelompokkan berdasarkan usia ke dalam pendidikan anak (pedagogi) dan pendidikan dewasa (andragogi). Andragogi atau pendidikan pada orang dewasa terjadi karena adanya perasaan tidak puas dalam memenuhi kebutuhannya. Kompleksnya kehidupan akan semakin menuntut individu untuk meningkatkan pengetahuannya dan mengembangkan kemampuannya. Istilah andragogi menurut Eliza Herijulianti dkk (2001: 3) berasal dari kata ando dan gogos yang berararti "memimpin" atau "membimbing". Seorang dikatakan dewasa tidak hanya dilihat dari segi biologis tetapi juga dari segi sosial dan psikologi.

Sedangkan pendidikan pada anak-anak atau pendagogi berasal dari bahasa Yunani yang terdiri dari dua kata yaitu paes yang artinya "anak-anak" dan gogos artinya "memimpin" dan kata atau akhiran/berarti "ilmu", jadi pendagogi adalah seni/ilmu untuk memimpin anak-anak. Dalam Undang-Undang Nomor 2 tahun 1989: 2 adalah usaha untuk menyiapkan peserta didik melalui kegiatan bimbingan, pengajaran, dan latihan agar dapat berperan di masa yang akan datang.

Terkait dengan pendidikan agama Islam yang berlaku di sekolah dasar, adapun yang menjadi tujuannya menurut Udin Wahyudin (2007: iii) adalah menumbuhkan dan meningkatkan keimanan, melalui pemberian dan pemupukan pengetahuan, penghayatan pengalaman, serta pengamalan peserta didik tentang agama Islam. Hal ini sebagaimana diungkapkan dalam kata pengantar Direktur PAI Pada Sekolah., Dr. H. Imam Tholhah, MA, yang menyatakan bahwa, pendidikan agama Islam di tingkat dasar bertujuan untuk:

1. Menumbuhkembangkan akidah melalui pemberian, pemupukan dan pengembangan pengetahuan, penghayatan, pengamalan, pembiasaan, serta pengalaman peserta didik tentang agama Islam sehingga menjadi manusia muslim yang terus berkembang keimanan dan ketakwaannya kepada Allah SWT.

2. Mewujudkan manusia Indonesia yang taat beragama dan berakhlak mulia, yaitu manusia yang berpengetahuan, rajin beribadah, cerdas, produktif, bertoleransi (tasamub), menjaga keharmonisan secara personal dan sosial serta mengembangkan budaya agama dalam komunitas sekolah.

Konsep pendidikan dasar yang dijelaskan di atas memang terkadang berbeda dengan kenyataanya. Konsep pendidikan yang diusung oleh ajaran-ajaran agama, sering kali menuai kritik dan protes. Girard (dalam Ahmad Faizin Karimi, 2012: 221) menyatakan bahwa agama adalah istilah lain bagi kegelapan terselubung yang menaungi manusia dalam usahanya untuk membela diri dengan tindakan preventif dan kuratif melawan kekerasannya. Selain itu, Fahmi Salatalohy (2004, 49-50), menyebutkan klaim-klaim kebenaran selalu muncul memberi justifikasi terhadap kebenaran agama-agama sendiri dengan menafikan kemungkinan kebenaran agama lain. Ketika terjadi stagnasi spiritual dan ketidakdewasaan masyarakat di dalam menerima pluralitas tampak ketika agama dijadikan alat justifikasi terhadap kekerasan sosial.

Berbagai perang dan tindak kekerasan yang mengatasanamakan agama juga telah menjadi catatan hitam perjalanan panjang sejarah manusia. Perang Salib, Perang 30 tahun, perang antara kelompok Budha Sinhala dengan Hindu Tamil di Sri Lanka, dan lain-lain. Perang 30 tahun (1618-1648) adalah perang antara penganut-penganut Katolik Roma dan penganut Reformis (Protestan). Perang ini diawali oleh pemberontakan umat Protestan Bohemia pada penguasa Katolik Austria yang kemudian menjalar hampir ke seluruh daratan Eropa. Perang ini diakhiri dengan perjanjian Munster pada tahun 1648, sekaligus sebagai awal dari kemerdekaan Kerajaan Belanda dari Spanyol (Simon Adams, 2007: 25). 
Berbagai peperangan sebagaimana disebutkan di atas, memperlihatkan contoh bagaimana agama ingin mendominasi masyarakat dan demi dominasi itu sendiri, bersedia memerangi agama lain. Inilah yang dimaksud bahwa klaim pemahaman kebenaran tentang agama yang baik dapat membentuk lahirnya sakralisasi dan fundamentalisasi agama. Namun pemahaman kebenaran tentang agama yang salah akan melahirkan radikalitas dan terorisme baik terhadap pengikut agamanya sendiri, terlebih bagi agama yang berbeda.

Yonky Karman (2010: 12) menyatakan bahwa agama mengakui kekerasan sebagai bagian dari realitas sebuah dunia yang tidak ideal (given reality), dunia insani, dunia yang sarat dengan hawa nafsu dan dosa. Agama tidak membenarkan kekerasan begitu saja. Namun secara fenomenologis, agam-agama formal tidak terlepas dari praktik-praktik kekerasan. Lebih lanjut, dalam pandangannya sebuah kekerasan dalam agama adalah hukuman yang dikenakan untuk anggota komunitas umat yang terbukti melanggar ajaran agama, yang dapat berupa hukuman cambuk, potong lengan, atau rajam. Sublimasi kekerasan yang lebih substansial dijumpai dalam sistem qurban agama-agama.

Lebih lanjut, terkait dengan kekerasan, maka kekerasan yang dimaksud dalam tulisan ini dapat diartikan sebagai tindakan yang dilakukan untuk melawan orang lain atau kelompok lain yang diakibatkan oleh konflik yang berkelanjutan. Kekerasan atau violence dalam bahasa Inggris memiliki banyak definisi. Walter (1976) menyatakan, kekerasan adalah pemaksaan atau force yang dilancarkan dengan merusak pihak lain. Selain itu, kekerasan menurut Lucien Van Liere (2010: 48) adalah sebuah "substansi" yang tidak mengarah ke sebuah objek yang statis, tetapi mengarah ke sebuah peristiwa yang dinamis. Dinamika itu terdiri dari (antara lain) perasaan, pengalaman, kesakitan, ketakutan dan keinginan: aspek-aspek yang tidak masuk menjadi sebuah definisi. Oleh karena itu, selalu ada "jarak" antara definisi kekerasan dan peristiwa yang "didefinisikannya". Artinya, sebuah definisi selalu memiliki kekurangan dan "tidak benar".

Dari berbagai penjelasan di atas, dapat ditarik beberapa indikator dari pengertian tindak kekerasan: pertama $a_{s}$ kekerasan terbuka yakni kekerasan yang dapat dilihat atau diamati secara langsung, seperti kerusuhan, tawauran atau hal-hal lain yang berkaitan dengan eksperesi tindakan yang berbentuk fisik. Kedua, kekerasan tertutup yakni kekerasan yang dilakukan secara diam-diam, sembunyi-sembunyi atau tidak dilakukan secara langsung, seperti melakukan ancaman, intimidasi, atau simbol-simbol tekanan psikis lain yang menyebabkan korban merasa takut atau tertekan. Ketiga, kekerasan agresif (offensive) yakni kekerasan yang dilakukan untuk mendapatkan sesuatu secara paksa seperti dalam bentuk perampasan, pencurian, pemerkosaan atau bahkan pembunuhan yang kesemuanya sudah dikategorikan sebagai perbuatan kriminal. Keempat, kekerasan defensif (defensive) yakni kekerasan yang dilakukan sebagai tindakan perlindungan terhadap kekuatan lain yang akan mengancam, seperti melakukan pemblokiran.

Dari tingkat (level) intensitas suatu kekerasan bisa meningkat dari kekerasan ringan atau potensi menjadi kekerasan tingkat sedang bahkan dapat berlanjut pada kekerasan tingkat berat, berupa tindak kriminal dalam pendidikan. Kekerasan disebut dalam bentuk potensi, bilamana memiliki indikator sebagai berikut: bersifat tetutup, berupa unjuk rasa untuk menyampaikan aspirasi, pelecehan nama baik seseorang, dan ancaman atau intimidasi. Bila kekerasan tertutup berubah menjadi konflik terbuka, unjuk rasa berubah menjadi bentrok, ancaman berubah menjadi tindakan nyata, dan kekerasan defensif menjadi ofensif, maka saat itu juga potensi berubah menjadi kekerasan. 


\section{KURIKULUM KEKERASAN PADA ANAK}

Les Parson (2009) menyatakan, bahwa siswa bukanlah satu-satunya pihak yang melakukan kekerasan atau intimidasi di sekolah. Para guru, kepala sekolah dan orangtua juga melakukan hal ini. Bersama-sama mereka membentuk budaya intimidasi di mana siswa terdapat pada pada peringkat paling bawah hieraki kekuasaan ini. Selain itu, dari pemberitaan surat kabar nasional yang dikompilasi Komisi Perlindungan Anaka Indonesia (KPAI) selama tahun 2007, dari 555 kasus kekerasan terhadap anak yang muncul di surat kabar, 11.8\% terjadi di sekolah. Ketika dengan metode yang sama dilakukan pada tahun 2008, angkanya tidak menurun, tetapi malahan meningkat menjadi 39\%. Angka-angka ini senada dengan pengaduan yang diterima KPAI, bahwa kekerasan terhadap anak di sekolah masih saja berlangsung, dari sekedar pelecahan kata-kata, kekerasan fisik, sampai pelecehan seksual, bahkan beberapa diantaranya menyebabkan kematian.

Tindak kekerasan sedang menginvasi sekolah, menggangu belajar mengajar dan mengurangi keprcayaan anak dan kepercayaan orang dewasa. Pelajar remaja yang baik bergabung dengan kelompok geng dan mempersenjatai dirinya untuk "proteksi", menyebabkan dirinya lebih beresiko. Hadi Supeno (2010: 95) mencatat, bahwa hampir 1,5 juta anak dilaporkan telah disalahgunakan secara fisik dan/atau seksual. Orangtua menyiksa anaknya tidak hanya melukai anaknya secara fisik dan psikologi tetapi juga "mengajari” anaknya menggunakan kekuatan untuk menyelesaikan konflik. Seringkali orangtua yang sama ini mengizinkan anaknya berperilaku kasar terhadap saudara-saudara kandungnya dan lain-lain.

Kasus perilaku kekerasan dalam pendidikan juga bervariasi: Pertama, kategori ringan, langsung selesai di tempat dan tidak menimbulkan kekerasan susulan atau aksi balas dendam oleh si korban. Untuk kekerasan dalam klasifikasi ini perlu dilihat terlebih dahulu, apakah kasusnya selesai secara intern di sekolah dan tidak diekspos oleh media massa ataukah tidak selesai dan diekspos oleh media massa. Kedua, kategori sedang namun tetap diselesaikan oleh pihak sekolah dengan bantuan aparat. Ketiga, kategori berat yang terjadi di luar sekolah dan mengarah pada tindak kriminal serta ditangani oleh aparat kepolisian atau pengadilan.

Persoalan ini semakin kompleks ketika ajaran agama yang dianggap mengandung kekerasan masuk ke dalam kurikulum pendidikan anak usia dasar. Teks agama-agama yang terkandung di dalamnya kemudian menuai kritik akibat kurangnya pemahaman orang terhadap agama, semisal kisah turunnya perintah mengenai penyembelihan anak yang termaktub dalam ajaran Alkitab Ibrani 11: 8-19 (17: 19). Sedangkan al-Qur'an menyebut kisah tersebut adalah antara Nabi Ibrahim dan putra pertamanya Nabi Ismail, sebagai berikut:

Maka tatkala anak itu sampai (pada umur sanggup) berusaba bersama-sama Ibrabim, Ibrabim berkata: "Hai anakeku sesunggubnya aku melihat dalam mimpi bahwa aku menyembelihmu. Maka fikirkanlah apa pendapatmu!" Ia menjawab: "Hai bapakku, kerjakanlah apa yang diperintahkan kepadamu; insya Allah kamu akan mendapatiku termasuk orang-orang yang sabar". (As-Shafat (37): 102).

Kisah mimpi yang dialami Nabi Ibrahim tersebut, pada orang awam yang salah memahami makna tekstual dan kontekstual ayat akan menjadi salah persepsi. Pada beberapa kasus pembunuhan yang terjadi beberapa waktu lalu di Indonesia, ada diantaranya tindak kasus pidana yang dilatar belakangi oleh mimpi. Seperti yang terjadi pada kasus pembunuhan orangtua terhadap anaknya sendiri di Sidoarjo (dalam AntaraNews.com) pada tanggal 11 Juni 2012. Pelaku 
mengaku sebelum membunuh anak kandungnya sendiri dirinya mendapatkan pesan dari sebuah mimpi.

Selain itu pada sisi ibadah jika dilihat dalam pelaksanaannya, ditemukan suatu hadits yang secara tegas menganjurkan orangtua untuk melakukan tindak tegas bagi anak yang tidak mau menjalankan ibadah. Hal ini sebagaimana dijelaskan dalam hadits Rasulullah SAW Abdul Muni'm Ibrahim (2015: 167) sebagai berikut: “Ajarkanlah shalat kepada anak-anak kalian ketika telah menginjak usia tujub tabun, dan pukullah jika meninggalkan shalat ketika telah memasuki usia sepuluh tabun." (Hadits Hasan)

Hadits di atas sebenarnya tidak menjadikan unsur kekerasan, yakni memukul lebih didahulukan ketimbang pendekatan edukatif lainnya. Hal ini terlihat dari pernyataan awal tentang tindakan tegas yang baru dapat dilakukan setelah melewati proses pengajaran dan telah cukup waktunya. Selain itu, dalam upaya pengendalian sosial, sebuah tindakan sudah sepantasnya dilakukan secara bertahap mulai dari sosialisasi sampai dengan pendektan preventif (mencegah), represif (menekan), persuasif (membujuk), dan koersif (tegas). Pada kasus hadits tersebut sebenarnya baru pada tahap preventif. Karena pada kenyataannya Nabi sendiri tidak pernah tercatat memukul anak maupun cucunya selama dalam pengasuhan. Sehingga ucapan nabi yang mengatakan "dan pukullah jika meninggalkan shalat ketika telah memasuki usia sepulub tahun" hanyalah berupa ancaman yang baru dapat diterapkan setelah melalui proses yang panjang.

Islam sendiri pada kenyataannya tidak membenarkan pemaksaan dalam beragama. Bagi Islam, jalan kebenaran dan kesesatan sudah jelas dan nyata untuk dapat dipahami oleh jiwa dan akal manusia. Tinggal bagaimana manusia mau menyikapi dan mengekplorasi potensi yang ada pada dirinya. Hal ini sebagaimana firman Allah SWT yang artinya;

Tidak ada paksaan untuk (memasuki) agama (Islam); sesunggubnya telab jelas jalan yang benar daripada jalan yang sesat. Karena itu barang siapa yang ingkar kepada Thaghut dan beriman kepada Allah, maka sesungguhnya ia telah berpegang kepada bubul tali yang amat kuat yang tidak akan putus. Dan Allah Maba Mendengar lagi Maha Mengetahui. (QS. al-Baqarah (2): 256).

Lebih lanjut, sebagai umat Islam maka sudah menjadi kewajiban baginya untuk menyampaikan amanah dan berlaku adil terhadap manusia. Termasuk terhadap orang-orang yang berbeda agama, serta tidak dibenarkan pula untuk menggangu mereka dan juga sebaliknya.

Katakanlah: "Hai orang-orang yang kafir (1) aku tidak akan menyembah apa yang kamu sembah.(2) Dan kamu bukan penyembah Tuhan yang aku sembah.(3) Dan aku tidak pernah menjadi penyembah apa yang kamu sembah.(4) Dan kamu tidak pernah (pula) menjadi penyembah Tuban yang aku sembah.(5) Untukmulah agamamu dan untukekulah agamaku (6)". (QS. AlKafirun (109): 1-6)

Berdasarkan berbagai penjelasan tersebut, maka tidak dapat dipungkiri bahwa agama tidak mengajarkan umatnya untuk melakukan kekerasan kepada orang lain. Agama juga mengajarkan agar umatnya menolong orang-orang yang ada disekitarnya serta terhadap orang yang membutuhkan pertolongan. Artinya dengan menolomg korban kekerasan, hal ini menunjukkan ketidaksetujuan agama terhadap terhadap kekerasan itu sendiri. Namun, ketika ajaran agama hanya dipahami secara sepotong-sepotng, dan ketika pesan agama hanya ditangkap berdasarkan huruf-hurufnya saja, maka muncullah sikap eksklusif dari suatu golongan dalam umat 
tersebut, dan pada akhirnya menumbuhkan ketertutupan dan permusuhan pada pemahaman yang berbeda.

\section{UPAYA MENANGKAL KEKERASAN PADA ANAK}

Kehidupan masyarakat yang semakin plural, seharusnya mampu untuk mendorong dan membentuk para pemeluk dan pemimpin agama untuk menumbuhkan semangat kerukunan antar agama. Sehingga aksi-aksi kekerasan yang muncul atas nama agama tidak langsung menjadi pemicu dan pembenaran aksi dari kekerasan selanjutnya. Dengan demikian setiap aksi yang ada hendaknya dapat dipahami dan dipelajari terlebih dahulu substansinya secara benar dengan menggunakan akal dan jiwa yang sehat. Allah SWT berfirman, yang artinya;

Hai orang-orang yang beriman, jike datang kepadamu orang fasik membawa suatu berita, maka periksalah dengan teliti, agar kamu tidak menimpakan suatu musibah kepada suatu kaum tanpa mengetabui keadaannya yang menyebabkan kamu menyesal atas perbuatanmu itu. (QS. Al-Hujarat (49): 6).

Dari ayat tersebut, sudah sepantasnya sebagai seorang muslim untuk tidak tergesa-gesa dalam menyikapi suatu persoalan. Pengambilan keputusan yang tidak tepat akan berdampak pada terciptanya persoalan yang baru. Terlebih setiap ajaran agama terutama ajaran Islam, tidak mentoleransi sebuah tindakan kekerasan dengan alasan yang jelas. Allah SWT berfirman yang artinya;

Barangsiapa yang membunuh seorang manusia, bukan karena orang itu (membunub) orang lain, atau bukan karena membuat kerusakan di muka bumi, maka seakan-akan dia telab membunub manusia selurubnya. Dan barang siapa yang memelihara kebidupan seorang manusia, maka seolab-olah dia telah memelibara kehidupan manusia semuanya. (QS. Al-Maidah (5): 32).

Selain itu pemerintah juga telah berupaya untuk melindungi hak-hak anak, sebagiamana yang terefleksi dalam batang tubuh UUD 1945 pasal 34, yang berbunyi: "fakir miskin dan anak terlantar dipelihara oleb negara". Implementasi undang-undang ini pula juga telah terealisasi dalam undang-undang kesejahteraan anak tahun 1979 dan dilanjutkan dengan keluarnya regulasi Pemerintah Indonesia, di tahun 2002 yang telah mentapkan Undang-Undang Perlindungan Anak dengan tujuan menjamin hak anak dan prinsip-prinsip yang tercantum dalam konvensi hak anak. dengan memunculkan pasal tambahan, yakni Pasal 28 Ayat (2) yang berbunyi : "setiap anak berhak. untuk kelangsungan hidup, tumbuh dan berkembang, serta memperoleh perlindungan dari kekerasan dan diskriminasi". Sangat jelas KHA pada pasal ini, yaitu pada kalimat "setiap anak berbak atas kelangsungan bidup, tumbuh dan berkembang" sebagai hak-hak dasar, sedangkan "perlindungan dari kekerasan dan diskriminasi" merupakan perlindungan khusus.

Selanjutnya, bagi masyarakat dan orangtua ada banyak cara yang juga dapat dilakukan untuk mencegah dan mengatasi terjadinya tindakan kekerasan pada anak-anak atas nama agama dan simbol-simbol lainnya. Diantaranya adalah dengan beberapa cara sebagaimana berikut;

1. Keluarga dan sekolah sebagai garda terdepan pendidikan bagi anak, hendaknya dapat memberikan pemahaman dan pembelajaran tentang hal-hal dasar yang wajib diketahui dan dapat dipelajari oleh anak, misalnya mengenai apa yang boleh dan tidak boleh dilakuakan. 
Sehingga jika ada permasalahan yang ada dan menyangkut pada dirinya, anak akan dapat segera menyadari dan diharapkan bertindak atau minimal menghindarinya.

2. Pembinaan bagi orangtua, keluarga atau kelompok-kelompok yang terlibat dalam pendidikan anak, perlu dilakukan dengan komprehensif untuk meberikan gambaran yang utuh tentang agama dan aplikasinya dalam kehidupan. Selain itu, orangtua sebagai pihak yang paling dekat hubungan kekerabatan dan sosialnya dengan anak, hendaknya lebih berhati-hati dalam mengawasi dan bertindak.

3. Apabila ditemukan lembaga atau instansi pendidikan, yakni keluarga, sekolah, dan masyarakat yang terbukti secara nyata melakukan ataupun mengajarkan tindak kekerasan atas nama agama ataupun simbol-simbol tertentu. Maka sudah menjadi kewajiban seorang warga negara yang baik untuk melaporkan hal tersebut kepada instansi-instansi yang berwenang.

Selain itu hal yang paling penting adalah sikap kita untuk belajar pada pengalaman dan berkehendak untuk lebih terbuka dan kritis dengan situasi yang dihadapi. Upaya membangun hubungan yang berpijak pada prinsip persamaan, keterbukaan, dan saling menghargai adalah wujud mutlak yang harus dilakukan untuk membenahi jalinan kusut hubungan sosial kemasyarakatan dengan sebuah sistem sosial yang adil, terbuka dan saling menghargai.

Sikap terbuka berarti sikap untuk mau menerima orang lain, menerima perbedaan pandangan dan menerima perbedaan pendapat dengan orang lain. Selain itu, juga ada inisiatif atau kehendak untuk mengafirmasi kelompok yang berbeda. Terbuka juga bukan berarti hanya sikap mau menerima, tapi juga sikap dalam bentuk kehendak untuk mengafirmasi orang lain. Arti terbuka juga yaitu sikap melebur atau menggabungkan pribadi atas pribadi lain yang berbeda. Artinya hubungan yang dibangun di atas prinsip keterbukaan tanpa meninggalkan indentitas masing-masing.

Kemudian para pemimpin harus ambil bagian dalam mencegah kekerasan atas nama agama yang sering terjadi di negeri ini dengan cara memberikan pembinaan dan pemahaman yang utuh dan menyeluruh mengenai substansi ajaran agamanya masing-masing yang memang mengajarkan kebaikan kepada umat. Kekerasan agama yang terjadi selama ini dilakukan oleh pihak-pihak yang begitu bersemangat dalam praktik ritual hidup keagamaan tetapi pengamalannya masih kurang, bahkan salah dalam menafsirkan agamanya.

\section{PENUTUP}

Kekerasan pada anak (child abuse) merupakan tindakan yang tidak diperkenakan dalam ajaran agama. Bahkan dalam kegiatan pendidikan, mengajarkan maupun menanamkan nilai-nilai agama pada anak-anak dengan cara kekerasan adalah sebuah tindakan kriminal. Sehingga paradigma seperti ini harus dihindari dan dan diganti dengan metode pembelajaran yang lebih manusiawi sesuai dengan kodratnya sebagai manusia.

Berangkat dari berbagai penjelasan penulis di atas mengenai pendidikan agama dan kekerasan pada anak, hendaknya kita juga dapat mempersiapakan anak sebagai generasi penerus yang kuat dalam segala aspek yang bersifat positif tanpa harus mengedepankan sisi-sisi kekerasan. Suatu generasi yang dapat mengangkat derajat orangtua, agama, bangsa dan negaranya dan bukan justru sebaliknya. 


\section{REFERENSI}

Adams, Simon. 2007. Atlas Eksplorasi dan Kerajaan. Jakarta: PT. Gelora Aksara Pratama.

Al-Qardhawi, Yusuf. 2013. Fiqh Jihad. Selangor, Malaysia: PTS Islamika SDN. BHD.

Arvin, Behrman Kliegman. 1996. Ilmu Kesehatan Anak Nelson. Jakarta: Penerbit Buku Kedoteran EGC.

Herijulianti, Eliza dkk. 2001. Pendidikan Kesehatan Gigi. Jakarta : Penerbit Buku Kedokteran EGC.

http://www.antaranews.com/berita/315362/polisi-tetapkan-tersangka-pelaku-pemb unuhananak-kandung, diakses tanggal 21 April 2015.

Ibrahim. Abdul Muni'm 2005. Mendidik Anak Perempuan. Jakarta : Gema Insani Press. Hlm. 167.

Ismail. Andar. 2008. Selamat Mengikuti Dia: 33 Renungan Tentang Kristus. Jakarta: Gunung Mulia.

Karimi, Ahmad Faizin. 2012. Think Diferent: Jejak Pikir Reflektif Seputar Intelektualitas, Humanitas dan Intelektualitas. Gresik: MUHI Press.

Karman, Yonky. 2010. Runtubnya Kepedulian Kita Fenomena Bangsa yang Terjebak Formalisme Agama. Jakarta: PT. Kompas Media Nusantara.

Lempp, Walter. 2003. Tafsir Alkitab: Kitab Kejadian 12: 4-25: 18. Jakarta: BPK Gunung Mulia.

Liere, Lucien Van. 2010. Menghancurkan Belenggu Kekerasan (Teologi dan Etika Kristen di Tengah Tantangan Globalisasi dan Terorisme. Jakarta: Gunung Mulia.

Linden’ Nico Ter. 2008. Cara Baru Membaca Injil Markus dan Matius. Jakarta: Gunung Mulia.

Parsons, Les. 2009. Bullied Teacher Student Guru dan Siswa yang Terintimidasi. Jakarta: Grasindo.

Salatalohy, Fahmi. 2004. Nasionalisme Kaum Pinggiran dari Maluku, Tentang Maluku, Untuk Indonesia. Yogyakarta: LKiS.

Sholikhin, Muhammad. 2010. Ritual dan Tradisi Islam Jawa. Yogyakarta: PT. Suka Buku.

Soeroso, Andreas. 2008. Sososiologi 2. Jakarta: Penerbit Quadra.

Supeno, Hadi. 2010. Kriminalisasi Anak (Tawaran Gagasan Radikal Peradilan Anak Tanpa Pemidanaan. Jakarta: PT. Gramedia Pustaka. Utama. Hlm. 95. 
Tim Pengembangan Ilmu Pendidikan. 2009. Ilmu dan Aplikasi Pendidikan. Cetakan Ketiga. Bandung: PT. Imperial Bhakti Utama.

Wahyudin, Udin, dkk. 2007. Get Smart Pendidikan Agama Islam. Bandung: Grafindo Media Pratama.

Yang, Liem Khiem. 1997. Jemaat berdoa. Jakarta: Gunung Mulia. 